\title{
Marine Stewardship Council (MSC) Certification of Arctic Fisheries: Processes and Outcomes
}

\author{
Geir Hønneland \\ Norwegian Institute of International Affairs (NUPI) and Fridtjof Nansen Institute (FNI), \\ Norway
}

\begin{abstract}
Certification according to private sustainability standards (ecolabelling) has become an important addition to public fisheries management in recent years. The major global ecolabel in terms of comprehensiveness and coverage is the Marine Stewardship Council (MSC) Fisheries Standard. Under the MSC Standard, the status of the fishery's target stocks, its impact on the wider ecosystem and the effectiveness of its management system are assessed. Becoming and remaining certified requires continuous behavioural adaptation from fisheries through a fine-meshed system of conditions attached to certification. In this article, MSC certification of two clusters of fisheries in Arctic waters is discussed, one large- and one small-scale. In the Barents Sea cod and haddock fisheries, the main obstacle to certification has been the fisheries' impact on endangered, threatened and protected (ETP) species and bottom habitats, and in order to remain certified beyond the first five-year certification period, the fishing companies have had to introduce a number of voluntary measures beyond what is required by law. In the local lumpfish fisheries in Greenland, Iceland and Norway, conditions attached to certification have been related to the effects of these fisheries on seabirds and marine mammals. Here essential parts of a management regime, such as biological reference points and harvest control rules, have come about as a direct result of MSC certification. MSC certification is no panacea, but it seems to have found a niche as a supplement to national legislation and international agreements.
\end{abstract}

Keywords: Marine Stewardship Council, ecolabelling, Arctic fisheries, Barents Sea

Responsible Editor: Nigel Bankes, Faculty of Law, University of Calgary, Canada

Received: July 2020; Accepted: September 2020; Published: December 2020

\footnotetext{
*Correspondence to: Geir Hønneland, email: ghonneland@fni.no

(C) 2020 Geir Hønneland. This is an Open Access article distributed under the terms of the Creative Commons Attribution-NonCommercial 4.0 International License (https://creativecommons.org/licenses/by-nc/4.0/), allowing third parties to share their work (copy, distribute, transmit) and to adapt it, under the condition that the authors are given credit, that the work is not used for commercial purposes, and that in the event of reuse or distribution, the terms of this license are made clear.

Citation: Geir Hønneland. "Marine Stewardship Council (MSC) Certification of Arctic Fisheries: Processes and Outcomes" Arctic Review on Law and Politics,Vol. 11, 2020, pp. 133-156. http://dx.doi.org/10.23865/arctic.v11.2488
} 


\section{Geir Hønneland}

\section{Introduction}

Certification by private sustainability schemes has over the past few years become a prerequisite for export-oriented fisheries around the world. The golden standard of seafood certification is accreditation by the Global Sustainable Seafood Initiative (GSSI), ${ }^{1}$ and the first global scheme to achieve that was the Fisheries Standard of the Marine Stewardship Council (MSC). ${ }^{2}$ Since its establishment in 1997, MSC has worked decisively not only to develop an ever more rigorous standard for certification, but also to get wholesale supply chains and retailers to commit to purchasing MSC certified seafood only. As a consequence, seafood exporters face not only lower prices for non-MSC certified products; they are effectively barred from the most lucrative markets if their fish is not MSC certified.

Becoming and remaining certified requires continuous behavioural adaptation from fisheries through a fine-meshed system of conditions attached to certification. The MSC Certification Requirements - which consist of the MSC Fisheries Standard and the MSC Fisheries Certification Process (FCP) - only apply to a limited extent to fishing companies as such. They primarily involve an assessment of the management systems, with requirements as to their outcome (e.g. status of target and bycatch stocks and other ecosystem components, such as bottom habitats), management measures (e.g. harvest control rules and biological reference points) and availability of information (e.g. in the form of stock assessments). Hence, the involvement of management authorities at the national and international levels is necessary; it is the interaction between fishing companies and management authorities that is supposed to drive the sustainability of fisheries forward. To be specific, when a fishery is certified with conditions, their representatives have to work with management authorities (or scientists or other stakeholders) to meet these conditions within set timelines in order to remain certified. In many instances, this implies that national laws, regulations and policies must be changed.

There is a burgeoning social science literature on private fisheries certification schemes in general, and the MSC in particular. Many contributions focus on the perceptions and effects of the MSC beyond fisheries management as such, addressing, inter alia, consumer willingness to pay for certified products, ${ }^{3}$ the legitimacy of the MSC Standard among stakeholders ${ }^{4}$ and the environmental, economic and social effects of MSC certification. ${ }^{5}$ This article takes an "inside" perspective on MSC certification, analysing the MSC Certification Requirements as a "semi-legislative"/"regulatory" system and evaluating the effects of certification. The research question is: to what extent has MSC certification affected fisheries management (i.e. regulations) and fishing practices (i.e. fisher behaviour) $?^{6}$ The empirical focus is on two clusters of fisheries in Arctic waters, one large- and one small-scale. The Barents Sea, to the north of Norway and Northwest Russia (see Map 1), is one of the most productive fishing grounds in the world. It is home to a typical large-scale fishery, with more than a hundred ocean-going trawlers (most of them Russian) taking part all year round. The 


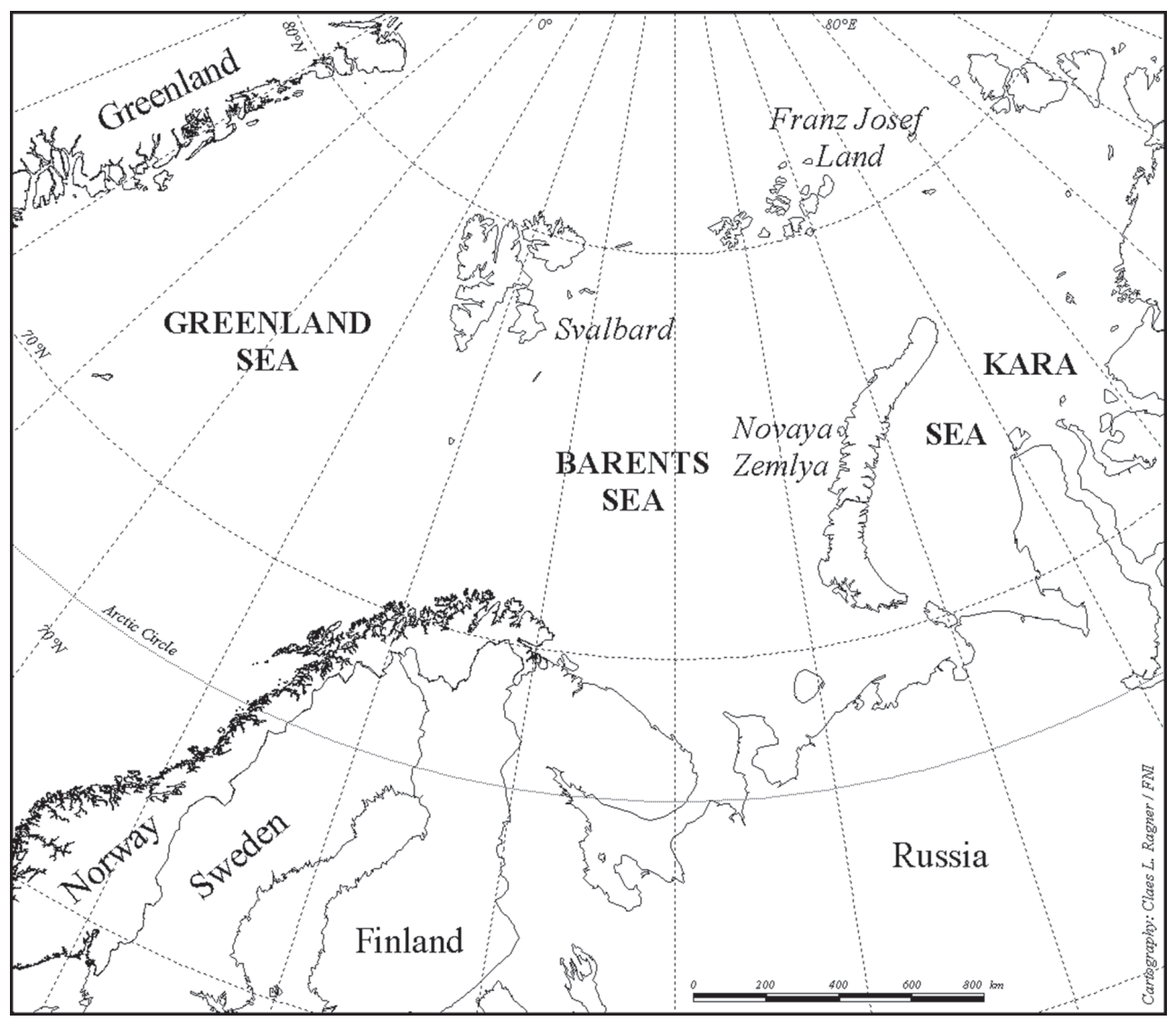

Map 1. The Barents Sea (copyright Fridtjof Nansen Institute)

main fishery is for demersal stocks (i.e. stocks living on the relatively shallow continental shelf), of which cod and haddock are commercially the most important. The second cluster is inshore fisheries for three stocks of one species, lumpfish, in three different Arctic states: Greenland, Iceland and Norway. Lumpfish is a semi-pelagic species (i.e. moving in the water column) fished mainly in fjords by local fishers and caught primarily for its roe. MSC coverage is high in all these fisheries. ${ }^{7}$

While lumpfish is managed at national level in Greenland, Iceland and Norway, the most important species in the Barents Sea fisheries are managed at the international level, by the Joint Norwegian-Soviet/Russian Fisheries Commission. The Commission was established by mutual agreement in $1975,{ }^{8}$ whereby Norway and the Soviet Union decided to treat cod and haddock as joint stocks to be shared 50/50 between the two states. ${ }^{9}$ Approximately $15 \%$ of the TAC for cod (and slightly less for other Barents Sea stocks) is traded in quota swaps with the EU, Faroe Islands, Greenland and Iceland. ${ }^{10}$ In addition to setting annual total allowable catches (TACs), the Joint Commission oversees scientific research cooperation, harmonization of technical 


\section{Geir Hønneland}

regulations and coordination of enforcement in various parts of the Barents Sea. There are two periods in the Joint Commission's history where Illegal, Unreported and Unregulated (IUU) fishing has taken place, in the early 1990s and a few years around 2005. Apart from this, Norway and Russia have generally succeeded in maintaining sustainable fishing practices in the Barents Sea. ${ }^{11}$

The empirical investigation is based on MSC assessment reports, and the results are summarized in Tables 1 and 2 below. Information on the fisheries' conditions, stakeholder comments, objections and work to meet conditions following certification is not generally available in aggregate form. To compile the necessary information, I have reviewed all assessment and reassessment reports, as well as annual surveillance audit reports (between 500-1000 pages per five-year certification period for each fishery), for the 15 fisheries (relating to three species and five stocks) covered in the investigation. ${ }^{12}$

In the following, an outline is first given of the MSC Certification Requirements, i.e. the procedural and substantive rules that govern MSC assessments. In the ensuing section, the results of the MSC assessment of the selected fisheries are presented, including information about the assessment process, such as stakeholder submissions and objections. Then follows a discussion of the extent to which MSC certification has affected fisheries management (i.e. regulations) and fishing practices (i.e. fisher behaviour).

\section{The MSC Certification Requirements}

The main actors in an MSC assessment are the Conformity Assessment Body (CAB), the MSC itself, the accreditation body Assurance Services International (ASI) and the fishery client seeking certification. The MSC is the scheme owner - it produces the standards and issues certificates, but does not get involved in the assessments directly except for providing technical reviews of the assessment reports. MSC is a non-governmental, non-profit organization headquartered in London. The assessments are performed by certification bodies, CABs, which compete for assignments among fishery clients on a commercial basis. CABs must be accredited by ASI in order to perform MSC assessments, and they are under constant scrutiny by the accreditation body through document review and physical inspection. The fishery client is anyone applying for certification for one or more fishing vessels - it may be a company, a regional or national association, or a group of companies or associations from different countries.

The MSC has three main types of programme documents, sometimes referred to collectively as the Certification Requirements: i) standards (containing substantive requirements for certification); ii) process requirements (to assessments according to the standards); and iii) guidance documents (on how the standards and process requirements are to be interpreted). These documents are revised in five-year cycles. In the following, the MSC Standard v2.01 ${ }^{13}$ and the FCP v2.1 ${ }^{14}$ are described. 


\subsection{The procedural requirements: the MSC Fisheries Certification Process}

The first step in a full assessment is to confirm that the fishery is within scope for MSC certification (FCP 7.4). A fishery is within scope if the target species are not amphibians, reptiles, birds or mammals (FCP 7.4.2.1) and poisons or explosives are not used (FCP 7.4.2.2). Further, the fishery must not be conducted under a controversial unilateral exemption to an international agreement (FCP 7.4.3), be overwhelmed by dispute ${ }^{15}$ or fail to contain a mechanism for solving disputes (FCP 7.4.5). Nor must it include entities that have been successfully prosecuted for forced or child labour (FCP 7.4.4).

The next step is to define the Unit of Assessment (UoA). The UoA shall include: i) the target stock(s); ii) the fishing method or gear type(s), vessel type(s) and/or practices; and iii) the group of vessels whose fishing operations are to be covered by the assessment (FCP 7.5.2). At a later stage in the process, the client - the company or group of companies seeking certification - must decide on the Unit of Certification (UoC) (FCP 7.5.3), i.e whether the whole UoA or just a part of it shall be covered by the specific certificate. Other vessels in the UoA, whose fishing activities have been covered by the assessment, are termed "other eligible fishers" and can join the certificate through a sharing agreement with the client (FCP 7.5.7). This is normally not done for free since the certification process involves considerable costs for the client.

The public announcement of an assessment takes place with the posting on the MSC website of the Announcement Comment Draft Report (ACDR) (FCP 7.15.1). The ACDR is an almost full version of the assessment report, but with indicative scoring ranges rather than specific scores (see below). Every assessment process involves a site visit, where the assessment team goes onsite to conduct interviews with stakeholders in the fishery, like scientists, managers, representatives of enforcement bodies, industry groups and non-governmental organizations (NGOs). The fishery is scored according to a fine-meshed system of Scoring Issues (SIs) - called the Assessment Tree (see next section) - attached to a number of Performance Indicators (PIs), within the three MSC Principles: Principle 1 (P1) on the status of the target stock(s), Principle 2 (P2) on the ecosystem impact of the fishery and Principle 3 (P3) on the management system. Specific requirements are assigned to each SI, the so-called Scoring Guideposts (SGs) for scores at 60,80 and 100. For a fishery to pass the assessment, no SI may score less than 60 , and the average weighted score of each of the three Principles must be at 80 or above. Hence, a fishery may score at 60 on one PI, but then it must achieve a 100 score on another PI in order to reach an average of 80 on that Principle. Most PIs consist of several SIs, and scores are given at increments of five points (FCP 7.17.5).

If a score between 60 and 80 is given for an individual SI, one or more "auditable and verifiable conditions [for certification]" must be set by the assessment team (FCP 7.18.1). The team shall draft conditions that, when implemented, shall result in improved performance to at least the 80 level within the five-year period during which the certificate is valid (FPC 7.18.1.3). The conditions shall include milestones 


\section{Geir Hønneland}

that specify the actions that the client must meet at each annual surveillance audit (see below) during the five-year certification period. The milestones shall, inter alia, identify "measurable improvements and outcomes (using quantitative metrics) expected each year" (FCP 7.18.1.4(a). Once the CAB has determined the conditions and milestones to be attached to the fishery, and has taken into account all available information as per the last day of the site visit, the assessment team completes the Client and Peer Review Draft Report (CPRDR) (FCP 7.19). The CPRDR goes to the client for comments and production of a Client Action Plan (CAP), in which they must detail how they intend to work towards meeting the annual milestones in the conditions set by the assessment team in order to bring the score up to 80 within the five-year certification period. The CPRDR also goes to the MSC Peer Review College, where two suitable peer reviewers are drawn from a pool of qualified experts. When the assessment team has responded to the comments from the client and peer reviewers, the Public Comment Draft Report (PCDR) is posted on the MSC website for public comments during a 30-day period (FCP 7.20). The PCDR also goes back to the peer reviewers for a second round of comments (FCP 7.20.9) and to the MSC for so-called Technical Oversight (FCP 7.20.10). The latter involves a "legality check" in which the scoring of each SI is controlled, taking into account the wording of the guideposts, the relevant guidance and interpretations as well as the assessment team's justification and documentation of its scores. When the team has responded to the comments from stakeholders, peer reviewers (second round) and the MSC, the Final Draft Report is produced and published on the MSC website (FCP 7.22), after which a 15 working day objection period follows (FCP 7.23).

The objection procedure is outlined in a separate annex to the FCP (Annex PD). Importantly, the procedure is not intended to result in a new assessment of the fishery against the Standard, but to determine whether the assessment team made any procedural errors (including using the available evidence incorrectly in determining the scores) "material to the determination or the fairness of the assessment" (PD 2.1.1.1). The objection procedure is open only to parties who made written submissions earlier in the assessment process (PD 2.1.2), and is led by an Independent Adjudicator (a civilian judge, attorney or professor of law) appointed by the MSC for a three-year period (PD 2.2). The Independent Adjudicator must first determine whether the filed objection is in the required form and that it has reasonable prospects of success (PD 2.4.1); further, that it is not spurious or vexatious (PD 2.4.2a), in which case it is dismissed. Then follows a 15-day period for consultations between the objector and the $\mathrm{CAB}$, organized by the Independent Adjudicator (PD 2.5). If agreement is not reached, 'written representation' commences, with defined procedures for correspondence over a 30-day period (PD 2.6). If agreement is still not reached, the case goes to formal adjudication (PD 2.7), including an oral hearing. The decision of the Independent Adjudicator is final (PD 2.7-2.8).

The MSC certificate is valid for five years. The state of the fishery, as well as progress against the set milestones for any conditions attached to the certificate, is 
monitored by the assessment team at annual surveillance audits (FCP 7.28). If a fishery client is behind target at a surveillance audit, remedial action is defined. If the fishery is not back on track for the next surveillance audit, it is suspended from MSC certification. A corrective action plan must be produced within 90 days of suspension, and if the terms of the plan are not complied with in the set timeframe, the certificate is withdrawn (FCP 7.28.16.2.b). If fishery clients intend to remain certified beyond the first five-year period, reassessment must be commenced no later than 90 days after the fourth anniversary of the certificate (FCP 7.30).

\subsection{The substantive requirements: the MSC Fisheries Standard}

The MSC Fisheries Standard is organized in the so-called Assessment Tree, which spells out the specific requirements (guideposts) against which a fishery is assessed: 89 SIs spread over 28 PIs within the three MSC Principles, with components as a mid-level category between principles and PIs. While the principles are thematically defined, the PIs can also be grouped into outcome, management and information indicators. Outcome indicators require that the fish stocks and other components of the ecosystem (like habitats) are at acceptable levels; for management indicators that adequate management measures are in place; and for information indicators that sufficient information exists to make appropriate management decisions.

Principle 1 (P1) is defined as follows:

\section{Principle 1: Sustainable target fish stocks}

A fishery must be conducted in a manner that does not lead to over-fishing or depletion of the exploited populations and, for those populations that are depleted, the fishery must be conducted in a manner that demonstrably leads to their recovery. (MSC Fisheries Standard, p. 5)

As follows from Figure 1, P1 consists of one outcome and one management component; several PIs also include elements of information indicators. Component 1 has only two PIs, one on the status of the stock (PI 1.1.1) and one on stock rebuilding (PI 1.1.2). In order to pass PI 1.1.1, i.e. achieve a score of 60, it must be likely (defined as at least $70 \%$ probability) that the target stock is above the point where recruitment would be impaired (PRI). To pass without condition, i.e. to score at or above 80 , it must be highly likely (at least $80 \%$ probability) that the stock is above PRI, and the stock must be fluctuating around a level consistent with the maximum sustainable yield (MSY). To achieve a 100 score, there must be a high degree of certainty (i.e. at least $95 \%$ probability) that the stock is above PRI and that it has been fluctuating around or been above MSY over several years (depending on the life span of the stock). PI 1.1.2 on stock rebuilding is only scored if SG 80 is not met for PI 1.1.1 and sets specific requirements for a rebuilding strategy. Component 2 of P1 comprises PIs related to the existence of a harvest strategy (PI 1.2.1), a harvest control rule (PI 1.2.2), information to support the harvest strategy (PI 1.2.3) and scientific stock assessments (PI 1.2.4) ${ }^{17}$ 


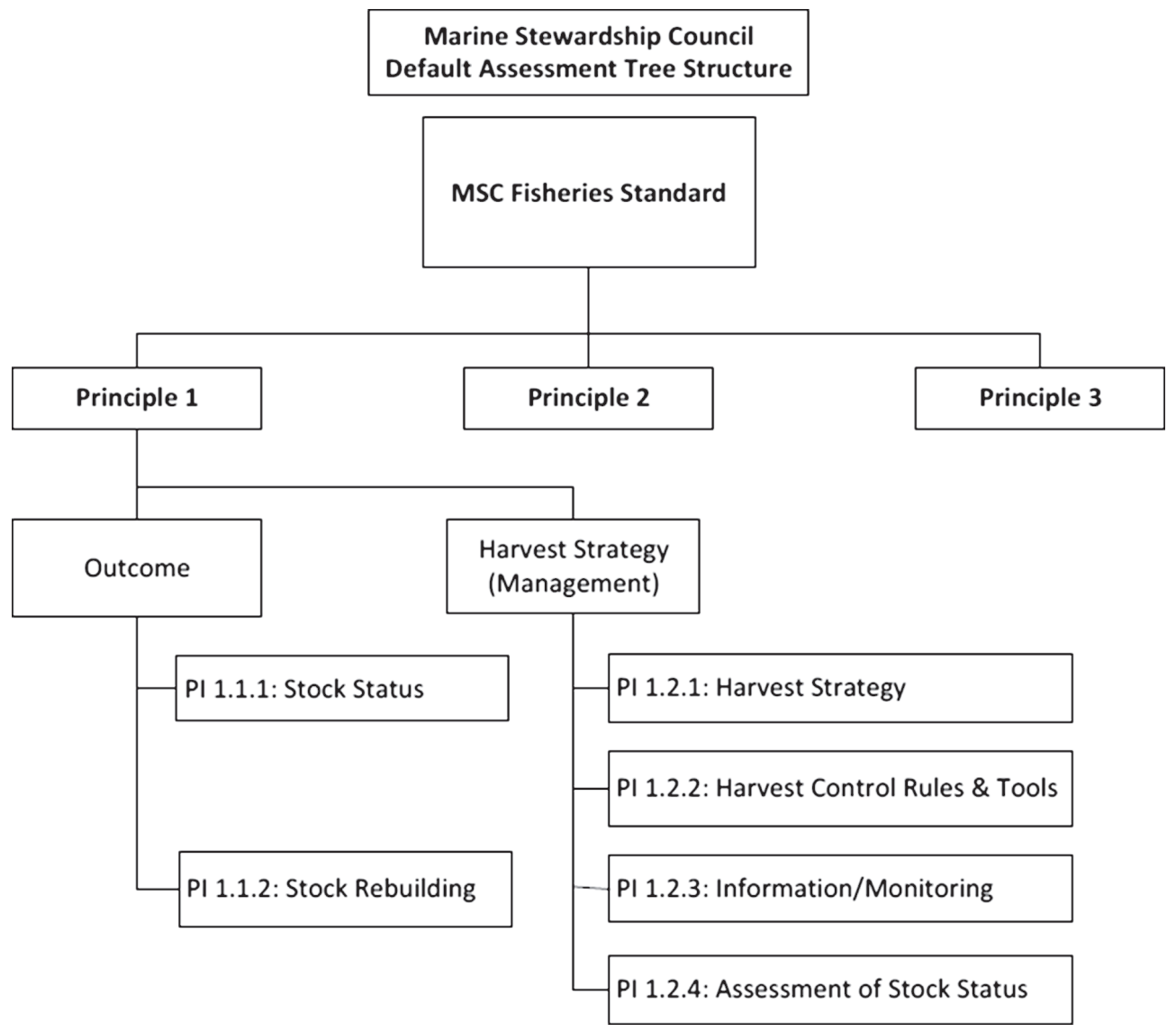

Figure 1: Principle 1 default assessment tree ${ }^{16}$

Principle 2 (P2) is defined as follows:

\section{Principle 2: Environmental impact of fishing}

Fishing operations should allow for the maintenance of the structure, productivity, function and diversity of the ecosystem (including habitat and associated, dependent and ecologically related species) on which the fishery depends. ${ }^{18}$

The P2 Assessment Tree (see Figure 2) has five thematically defined Components, on primary species; secondary species; endangered, threatened and protected (ETP) species; habitats and the wider ecosystem. Primary and secondary species both concern bycatch, the former species managed by biological reference points, the latter species that are not. Each Component is split into PIs on outcome, management and information, respectively. P2 is clearly the most complex of the three MSC Fisheries Standard Principles. Not only does it contain a higher number of SIs than P1 and P3 taken together (49, as opposed to 21 and 19, respectively), it also has a more comprehensive set of guidlines for interpretation and scoring. Since 2015, assessment teams 


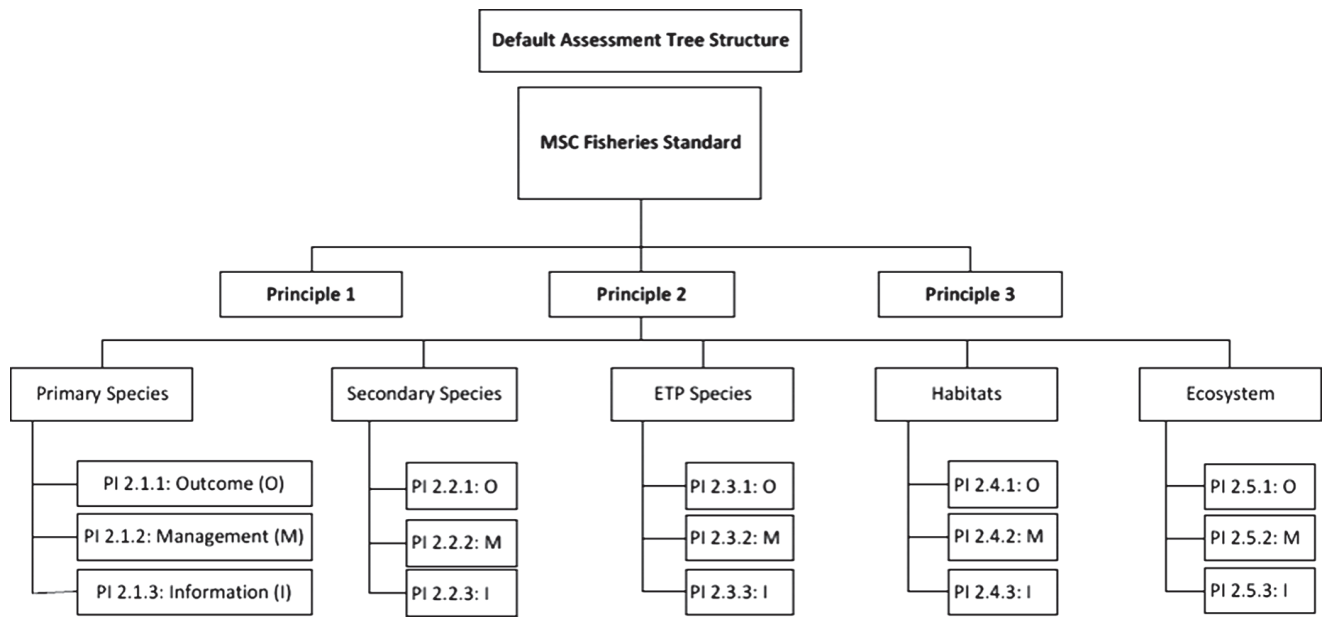

Figure 2: Principle 2 default assessment tree ${ }^{19}$

must not only assess the environmental impacts of the client fishery (the UoA), but also the accumulative impact of all MSC fisheries in the same region.

Principle 3 (P3) is defined as follows:

\section{Principle 3: Effective management}

The fishery is subject to an effective management system that respects local, national and international laws and standards and incorporates institutional and operational frameworks that require use of the resource to be responsible and sustainable. ${ }^{20}$

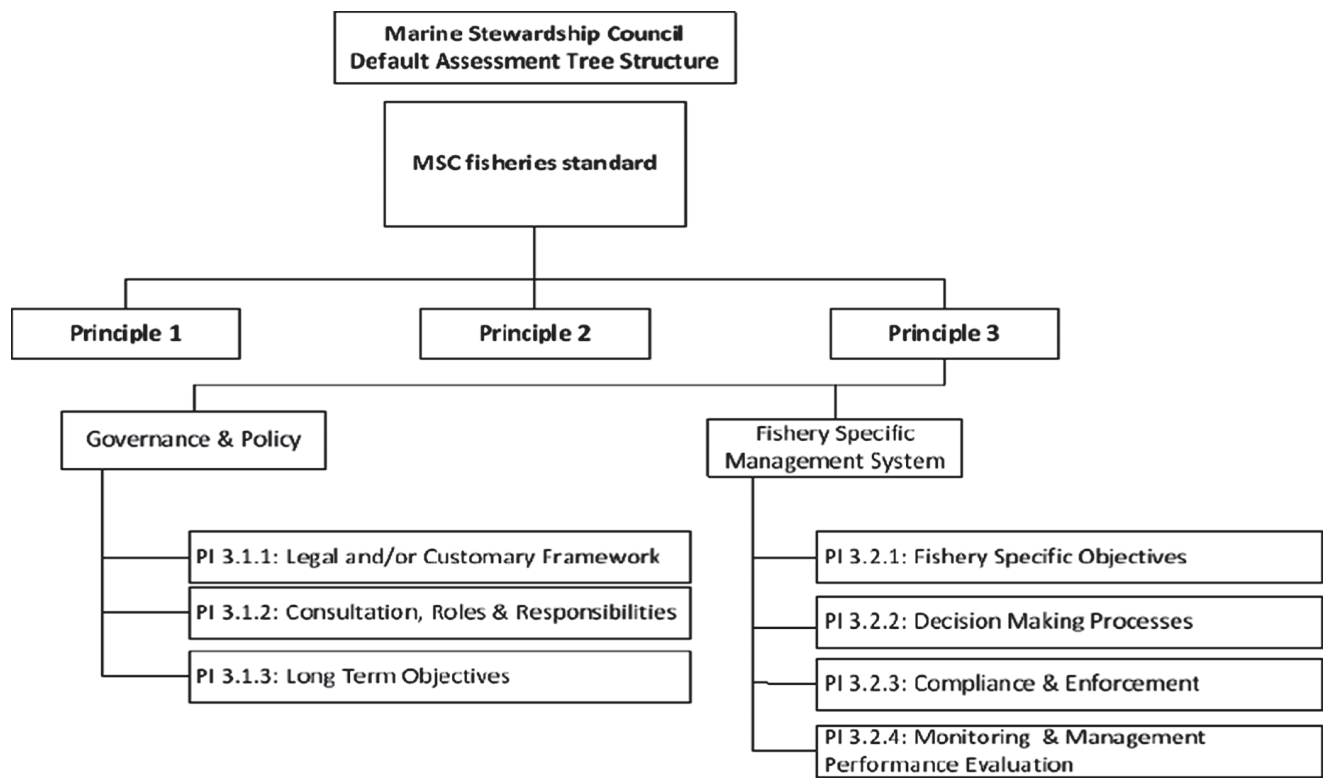

Figure 3: Principle 3 default assessment tree ${ }^{21}$ 


\section{Geir Hønneland}

P3 is split into two components (see Figure 3): one on the wider management framework of the fishery (at both the national and international levels) and one on the fishery-specific management system, i.e. the system directly involved in the management of the UoA fishery. While P1 and P2 mainly focus on the status of ecosystem components and the appropriateness of specific management measures (whether they have, or are likely to have, the intended effects), P3 is about structure and process, e.g. whether appropriate legislation (PI 3.1.1), dispute-resolution mechanisms (PI 3.1.1), opportunities for industry and other stakeholder involvement in the management process (PI 3.1.2) and appropriate objectives for the fishery (PIs 3.1.3 and 3.2.1) are in place.

\section{MSC certification of Arctic fisheries: processes}

We now move to an analysis of how the MSC Certification Requirements have been applied in practice in selected Arctic fisheries. What potentially dictates behavioural adaptation are the conditions attached to MSC certificates, the specific requirements for improvements that must be achieved during the five years the certificates are valid. While the contents of the conditions are presented in the next section, the present section focuses on the processes that led to them. Conditions follow from the expert opinion of the assessment teams appointed by the $\mathrm{CABs}$ (one expert per Principle), but are influenced by input from peer reviewers, stakeholders and objectors to certification and, in the last instance, the MSC's Independent Adjudicator. ${ }^{22}$

\subsection{Cod and haddock in the Barents Sea}

The first two Barents Sea fishery clients to apply for MSC certification, both in 2008, were the Norwegian Seafood Council and the Hong Kong-based Russian company Ocean Trawlers/Three Towns Capital (Ocean Trawlers henceforth). This difference in client structure reflects the different approaches to MSC certification taken by the two major fishing nations in the Barents Sea. In Norway, industry organizations like the Seafood Council and (later) the Norwegian Fishermen's Association pay for the assessments and let the entire Norwegian fleet be covered by the certificate. In Russia, individual companies seek their own certificate.

The two initial assessments took 19 and 22 months to complete, respectively. Average (and median) duration of the initial assessments of Barents Sea cod and haddock fisheries was 17 months. The Norwegian fishery had three conditions attached to it, all for P2 (relating to bycatch, ETP species and habitats), while the Russian fishery had six, two for each principle. Of the latter, the P1 and P3 principles were quickly closed at the first annual surveillance audits, while the P2 conditions, on bycatch and habitats, remained open until the fourth surveillance audit. ${ }^{23}$ All conditions for both fisheries were closed during the first certification 
period, but the Norwegian fishery had two new P2 conditions at reassessment; the Russian fishery no longer had any conditions. The other Russian fisheries that followed had either no conditions or conditions on P2 only, particularly related to ETP species and habitats.

While Norway and Russia account for the majority of Barents Sea fisheries as mentioned above, the two coastal states keep approximately $85 \%$ of the cod TAC for themselves - a number of other states are also involved. After the first Norwegian and Russian fisheries were certified in 2010, UK, German, French, Faroe and Icelandic fisheries followed suit in 2012, a Spanish fishery in 2013 and a Greenlandic one in 2015. With this, practically all the Barents Sea cod and haddock fisheries are MSC certified. With the exception of the Greenlandic fishery, none of the third-country fisheries received any stakeholder submissions. With the exception of the combined UK/German (UK/DFFU/Doggerbank) fishery, which also had some conditions on P3 related to the status of the Protection Zone around Svalbard, ${ }^{24}$ all conditions were on P2, in particular 2.4 related to habitats.

Table 1. Assessment and reassessment results of cod and haddock fisheries in the Barents Sea recertified as per 2019, compiled by the author based on assessment reports available on the MSC website (see Appendix 1)

\begin{tabular}{|c|c|c|c|c|}
\hline \multicolumn{5}{|c|}{ Initial assessment } \\
\hline Fishery/client ${ }^{\star}$ & $\begin{array}{l}\text { Announced/ } \\
\text { certified }\end{array}$ & Conditions & $\begin{array}{l}\text { Stakeholder } \\
\text { submissions }{ }^{\star \star}\end{array}$ & Objections \\
\hline $\begin{array}{l}\text { Norway (Norw. } \\
\text { Seafood Council) }\end{array}$ & $\begin{array}{l}3.9 .2008 / \\
26.4 .2010\end{array}$ & $\begin{array}{l}\text { - PIs 2.1.1, 2.3.3, } \\
2.4 .1\end{array}$ & $\begin{array}{l}\text { - WWF-Norway (a number } \\
\text { of comments across all } \\
\text { three principles) } \\
\text { - Directorate of Fisheries } \\
\text { (non-material) }\end{array}$ & None \\
\hline $\begin{array}{l}\text { Ocean Trawlers } \\
\text { (Russia) }\end{array}$ & $\begin{array}{l}24.12 .2008 / \\
24.10 .2010\end{array}$ & $\begin{array}{l}- \text { PIs } 1.2 .1,1.2 .2, \\
1.2 .3,2.1 .1,2.1 .2, \\
2.4 .1,2.4 .2,3.1 .2, \\
3.1 .3\end{array}$ & $\begin{array}{l}\text { - WWF-Russia (a number of } \\
\text { comments across all three } \\
\text { principles) }\end{array}$ & None \\
\hline $\begin{array}{l}\text { UK Fisheries/ } \\
\text { DFFU/ } \\
\text { Doggerbank } \\
\text { (UK/Germany) }\end{array}$ & $\begin{array}{l}13.1 .2011 / \\
3.5 .2012\end{array}$ & $\begin{array}{l}- \text { PIs 2.4.1, 3.1.1, } \\
\quad 3.1 .2,3.2 .2,3.2 .5\end{array}$ & None & None \\
\hline $\begin{array}{l}\text { Saint Malo/ } \\
\text { Euronor (France) }\end{array}$ & $\begin{array}{l}2.9 .2010 / \\
19.4 .2012\end{array}$ & - PIs 2.4.1, 2.4.1 & None & None \\
\hline $\begin{array}{l}\text { Faroe Islands/ } \\
\text { Iceland }\end{array}$ & $\begin{array}{l}28.6 .2011 / \\
16.8 .2012\end{array}$ & None & None & None \\
\hline FIUN (Russia) & $\begin{array}{l}22.3 .2012 / \\
25.6 .2013\end{array}$ & $\begin{array}{l}- \text { PIs } 2.1 .1,2.1 .2 \text {, } \\
\quad 2.4 .1,2.4 .2,3.1 .2\end{array}$ & $\begin{array}{l}\text { - American Bird } \\
\text { Conservancy (impact on } \\
\text { seabirds (only for longline)) }\end{array}$ & None \\
\hline
\end{tabular}


Geir Hønneland

Table 1. (Forstat)

\begin{tabular}{|c|c|c|c|c|}
\hline \multicolumn{5}{|c|}{ Initial assessment } \\
\hline Fishery/client* & $\begin{array}{l}\text { Announced/ } \\
\text { certified }\end{array}$ & Conditions & $\begin{array}{l}\text { Stakeholder } \\
\text { submissions }^{\star \star}\end{array}$ & Objections \\
\hline AGARBA (Spain) & $\begin{array}{l}7.6 .2012 / \\
28.11 .2013\end{array}$ & $\begin{array}{l}\text { - PIs } 2.1 .3,2.3 .2- \\
\quad 2.4 .3\end{array}$ & None & None \\
\hline $\begin{array}{l}\text { Strelets/Eridan } \\
\text { (Russia) }\end{array}$ & $\begin{array}{l}21.3 .2013 / \\
6.5 .2014\end{array}$ & None & $\begin{array}{l}\text { - WWF-Russia } \\
\text { (PI 2.4.2) }\end{array}$ & None \\
\hline Greenland & $\begin{array}{l}5.8 .2013 / \\
5.5 .2015\end{array}$ & - PI 2.4 .3 & $\begin{array}{r}\text { - WWF-Germany } \\
\text { (PIs 2.4.1-2.4.3) }\end{array}$ & $\begin{array}{l}\text { WWF-Germany } \\
\text { (PIs 2.4.1-2.4.3) }\end{array}$ \\
\hline $\begin{array}{l}\text { Arkhangelsk Trawl } \\
\text { Fleet (Russia) }\end{array}$ & $\begin{array}{l}24.10 .2014 / \\
26.1 .2016\end{array}$ & $\begin{array}{l}\text { - PIs } 2.3 .1,2.3 .2 \text {, } \\
2.3 .4,2.4 .2,2.4 .3\end{array}$ & $\begin{array}{l}\text { - WWF-Russia } \\
\text { (PI 2.4.2) }\end{array}$ & None \\
\hline $\begin{array}{l}\text { Oceanprom } \\
\text { (Russia) }\end{array}$ & $\begin{array}{l}7.12 .2017 / \\
11.6 .2019\end{array}$ & - PIs 2.3.2, 2.3.3 & None & None \\
\hline $\begin{array}{l}\text { Murmanseld } 2 \\
\text { (Russia) }\end{array}$ & $\begin{array}{l}22.10 .2018 / \\
5.3 .2020\end{array}$ & $\begin{array}{l}\text { - PIs 2.3.2, 2.4.1, } \\
\quad 2.4 .2\end{array}$ & $\begin{array}{l}\text { - WWF-Germany and } \\
\text { WWF-Russia (PIs 2.4.1, } \\
\text { 2.4.2) }\end{array}$ & $\begin{array}{l}\text {-WWF-Germany } \\
\text { and WWF-Russia } \\
\text { (PIs 2.4.1, 2.4.2) } \\
\text { (partial acceptance) }\end{array}$ \\
\hline \multicolumn{5}{|c|}{ Reassessment } \\
\hline Fishery/client ${ }^{\star}$ & $\begin{array}{l}\text { Announced/ } \\
\text { certified }\end{array}$ & Conditions & $\begin{array}{l}\text { Stakeholder } \\
\text { submissions }^{\star \star}\end{array}$ & Objections \\
\hline $\begin{array}{l}\text { Norway (Norw. } \\
\text { Fishermen's } \\
\text { Association) }\end{array}$ & $\begin{array}{l}16.12 .2014 / \\
6.10 .2015\end{array}$ & - PIs $2.3 .1,2.4 .1$ & $\begin{array}{l}\text { - WWF-Norway (PIs 2.4.1- } \\
\text { 2.4.3) }\end{array}$ & None \\
\hline $\begin{array}{l}\text { Ocean Trawlers } \\
\text { (Russia) }\end{array}$ & $\begin{array}{l}14.10 .2014 / \\
20.9 .2016\end{array}$ & None & $\begin{array}{l}\text { - WWF-Germany (PIs 2.4.1- } \\
\text { 2.4.3) }\end{array}$ & $\begin{array}{l}\text { - WWF-Germany } \\
\text { (PIs 2.4.1-2.4.3) } \\
\text { (compromise } \\
\text { achieved before oral } \\
\text { hearing) }\end{array}$ \\
\hline $\begin{array}{l}\text { UK Fisheries/ } \\
\text { DFFU/ } \\
\text { Doggerbank } \\
\text { (UK/Germany) }\end{array}$ & $\begin{array}{l}12.8 .2016 / \\
14.11 .2017\end{array}$ & - PIs 2.3.2-2.4.3 & -WWF-Germany (PI 2.4.1) & None \\
\hline $\begin{array}{l}\text { Faroe Islands/ } \\
\text { Iceland }\end{array}$ & $\begin{array}{l}8.9 .2016 / \\
21.8 .2017\end{array}$ & None & None & None \\
\hline $\begin{array}{l}\text { Saint Malo/ } \\
\text { Euronor (France) }\end{array}$ & $\begin{array}{l}22.9 .2016 / \\
13.10 .2017\end{array}$ & - PIs 2.4.1-2.4.3 & None & None \\
\hline $\begin{array}{l}\text { FIUN cod and } \\
\text { haddock }\end{array}$ & $\begin{array}{l}20.7 .2017 / \\
28.8 .2018\end{array}$ & - PI 2.4 .2 & None & None \\
\hline $\begin{array}{l}\text { Strelets/Eridan } \\
\text { (Russia) }\end{array}$ & $\begin{array}{l}26.9 .2017 / \\
2.4 .2019\end{array}$ & None & None & None \\
\hline Greenland & $\begin{array}{l}29.9 .2017 / \\
30.4 .2019\end{array}$ & None & None & None \\
\hline AGARBA (Spain) & $\begin{array}{l}24.5 .2018 / \\
26.4 .2019\end{array}$ & None & $\begin{array}{l}\text { - WWF-Germany } \\
\text { (PIs 2.4.1, 2.4.2) }\end{array}$ & None \\
\hline
\end{tabular}

*) The official names of the fisheries in the MSC system and the clients have been shortened here to save space.

**) Only submissions following publication of the PCDR are included in the table; many fisheries also received stakeholder submissions at earlier stages of the assessment. Technical oversight comments from MSC are not included although formally they fall under stakeholder comments.

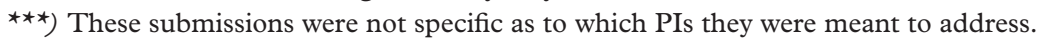


Of the 12 fisheries that have gone through initial assessment in the Barents Sea cod and haddock fisheries, seven received one or more stakeholder submissions. Six were from various regional offices of the WWF: WWF-Germany, WWF-Norway and WWF-Russia. The WWF's comments to the first two assessments were extensive and spanned all three MSC Principles, while all subsequent submissions, including the ensuing reassessments, addressed habitat effects only. This was also the topic of the two objections lodged in the initial assessments (to the Greenlandic fishery and one of the Russian companies, Murmanseld 2), both by WWF-Germany, the last one jointly with WWF-Russia. The objection to the Greenlandic fishery was lodged in October 2014 and formally dismissed by Independent Adjudicator Michael Lodge five months later, after extensive communication between the parties. During this exchange of proposals and counter-proposals, the CAB (Intertek Fisheries Certification) had agreed to reduce some of its scores and introduce a new condition on PI 2.4.3 related to the availability of information on bottom habitats. WWF filed a similar objection to the reassessment of Ocean Trawlers, commenced in 2014 and completed two years later, which also received an objection to the scoring of PIs 2.4.1-2.4.2. The Notice of Objection was submitted in April 2016 and formally withdrawn by the objector five months later. After extensive written consultations between the CAB (Acoura Marine), the client and the objector, facilitated by Independent Adjudicator Eldon V.C. Greenberg, the parties reached agreement on the eve of the scheduled oral hearings in London. No changes were made in the scoring of the fishery, but several clarifications were added to the text of the assessment report.

Three years later, WWF-Germany and WWF-Russia jointly objected on similar grounds to the certification of the Russian company Murmanseld 2, which was undergoing initial assessment by the certification body DNV GL. Essentially, WWF argued that the assessment team had failed to identify vulnerable marine ecosystems within the area of the fishery and scored the habitat performance indicator without considering quantitative research data. This objection went through the entire objection procedure laid down in the FCP: initial consultations and exchange of written representations followed by formal adjudication including oral hearings and subsequent correspondence before the Independent Adjudicator made his final decision. In the event, Independent Adjudicator John McKendrick QC, basing his decision on the parties' submissions, the MSC Certification Requirements and Interpretation $\log ,{ }^{25}$ as well as "principles of English [...] administrative law", ${ }^{26}$ to a large extent accepted the premises for WWF's objection. In his 25-page long Post Hearing Decision, he concluded by remanding the case to the $\mathrm{CAB}$ for rescoring and the introduction of two new conditions to the certificate. WWF objected to this conclusion as they had wanted a larger reduction in scores, but in his Final Decision the Independent Adjudicator dismissed this objection and accepted the CAB's revised Final (Assessment) Report. Hence, as a result of the objection new conditions were attached to the certificate, although they were not as strict as demanded by WWF. 


\section{Geir Hønneland}

\subsection{In-shore lumpfish in Greenland, Iceland and Norway}

Unlike the Barents Sea fisheries, which are operated by large trawlers plying the oceans for months on end, the Arctic lumpfish fishery is a typical small-scale, local fishery. It is conducted by small vessels, often one-man boats, using gillnets in fjords and close to shore. Lumpfish is caught for its roe, which is largely exported.

The first lumpfish fishery to enter MSC assessment was the Icelandic fishery, in 2013. The assessment took 22 months to complete. The Greenlandic fishery followed a year later and the Norwegian in 2016; these took 16 and 15 months, respectively. ${ }^{27}$ All fisheries received stakeholder comments (two each for the Greenlandic and Norwegian and five for the Icelandic), and two of them had an objection lodged against them (the Greenlandic and Icelandic fisheries). Stakeholders providing comments ranged from fishing associations, local and international NGOs and a research institute. The objectors were the US Animal Welfare Institute (for the Icelandic fishery) and BirdLife International (for the Greenlandic fishery).

In its objection to the certification of the Icelandic fishery, the US Animal Welfare Institute claimed that there was "significant information lacking in the assessment on known bycatch of cetacean species in this fishery. Entanglements of minke and humpback whales, common dolphins and harbor porpoise in the Icelandic lumpfish gillnet fishery have been noted in both scientific and popular literature." ${ }^{28}$ However, Independent Adjudicator Michael Lodge dismissed the objection on procedural grounds.

BirdLife International's objection during the assessment of the Greenlandic fisheries was also processed quickly, in less than two months. The objection related in its entirety to bycatch of birds, but it addressed all three elements of the bycatch component of the Assessment Tree: outcome (status of the stocks), management and information. The objector claimed, inter alia, that it is "near-impossible to quantify bycatch [of, e.g., common eider and common guillemot] adequately and, further, to determine whether this is hindering the full recovery of seabird populations that are increasing in number after over-harvesting." 29 Further, the absence of mitigation measures and a strategy to avoid bycatch of birds was highlighted. Facilitated by Independent Adjudicator Melanie Carter, agreement was reached between the objector and the $\mathrm{CAB}$, in close communication with the fishery client, after one round of written consultations. As a result, three new conditions were introduced related to bycatch of birds in the fishery: one for the outcome, one for the management and one for the information PI.

The Greenland fishery met all its conditions during the five-year certification period and entered reassessment in 2019. It was reassessed in 2020 with four new conditions, again all related to the fishery's effects on seabirds. ${ }^{30}$ But this time no stakeholder comments were received, or objections lodged. The Icelandic fishery, on the other hand, never made it to reassessment. At the third annual surveillance audit, in 2017, new information on seabirds was made available to the assessment 
Table 2. Assessment and reassessment results of inshore lumpfish fisheries in Greenland, Iceland and Norway certified as per 2019, compiled by the author based on assessment reports available on the MSC website (see Attachment 1)

\begin{tabular}{|c|c|c|c|c|}
\hline \multicolumn{5}{|c|}{ Initial assessment } \\
\hline Fishery/client* & $\begin{array}{l}\text { Announced/ } \\
\text { certified }\end{array}$ & Conditions & Stakeholder submissions ${ }^{\star \star}$ & Objections \\
\hline Iceland lumpfish & $\begin{array}{l}19.2 .2013 / \\
23.12 .2014\end{array}$ & $\begin{array}{c}- \text { PIs } 2.2 .2 \text {, } \\
2.2 .3\end{array}$ & $\begin{array}{l}\text { - Fuglaverndarfelag Islands } \\
\text { (Fuglavernd) (PI 2.2.3) } \\
\text { - Environmental Investigation } \\
\text { Agency (US) (PIs 2.2.1-2.2.3) } \\
\text { - Animal Welfare Institute (US) } \\
\text { (PIs 1.2.1, 2.2.2, 2.2.3, 3.1.4) } \\
\text { - Royal Greenland and } \\
\text { KNAPK (Greenland Fishing } \\
\text { and Hunting Association) } \\
\text { (procedural) } \\
\text { - Dr. Reiner Froese, GEOMAR } \\
\text { Helmholz-Centre for Ocean } \\
\text { Research (general P1 } \\
\text { comments) }\end{array}$ & $\begin{array}{l}\text { - Animal Welfare } \\
\text { Institute (US) } \\
\text { (dismissed on } \\
\text { procedural } \\
\text { grounds) }\end{array}$ \\
\hline $\begin{array}{l}\text { Greenland } \\
\text { lumpfish }\end{array}$ & $\begin{array}{l}1.4 .2014 / \\
13.8 .2015\end{array}$ & $\begin{array}{l}- \text { PIs } 1.2 .1 \text {, } \\
\text { 1.2.2, 2.2.1, } \\
\text { 2.2.2., 2.2.3, } \\
\text { 3.2.4 }\end{array}$ & $\begin{array}{l}\text { - BirdLife International (PIs } \\
\text { 2.2.1-2.2.3) } \\
\text { - National Association of Small } \\
\text { Boat Owners (general P1/P2 } \\
\text { comments) }\end{array}$ & $\begin{array}{l}\text { - BirdLife } \\
\text { International } \\
\text { (settled by } \\
\text { agreement) }\end{array}$ \\
\hline Norway lumpfish & $\begin{array}{l}11.7 .2016 / \\
6.10 .2017\end{array}$ & $\begin{array}{l}- \text { PIs } 1.2 .2 \text {, } \\
\text { 1.2.4, 2.3.1, } \\
\text { 2.3.2 }\end{array}$ & $\begin{array}{l}\text { - BirdLife International (PIs } \\
\text { 2.3.1-2.3.3) } \\
\text { - WWF-Germany (general } \\
\text { comments across all three } \\
\text { principles) }\end{array}$ & None \\
\hline
\end{tabular}

Reassessment/second attempt at initial assessment

\begin{tabular}{lllll}
\hline Fishery/client & $\begin{array}{l}\text { Announced/ } \\
\text { certified }\end{array}$ & Conditions & $\begin{array}{l}\text { Stakeholder } \\
\text { submissions }\end{array}$ & Objections \\
\hline Greenland & $12.8 .2019 / \mathrm{N} / \mathrm{A}^{\star \star \star}$ & - PIs 2.2.2, 2.2.3, & $\mathrm{N} / \mathrm{A}^{\star \star \star}$ & $\mathrm{N} / \mathrm{A}^{\star \star \star}$ \\
lumpfish & & $2.3 .2,3.2 .3$ & \\
Iceland & $18.3 .2020 / \mathrm{N} / \mathrm{A}^{\star \star \star \star}-\mathrm{PIs} 2.2 .1,2.2 .2$, & $\mathrm{N} / \mathrm{A}^{\star \star \star \star}$ & $\mathrm{N} / \mathrm{A}^{\star \star \star \star}$ \\
lumpfish & $2.2 .3,2.3 .2^{\star \star \star \star \star}$ & & \\
\hline
\end{tabular}

*) The official names of the fisheries in the MSC system and the clients have been shortened here to save space.

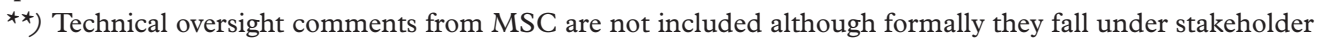
comments.

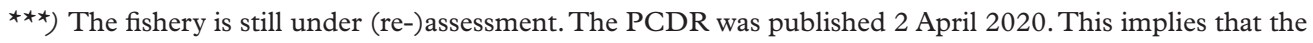
report had been through peer review, but the deadline for stakeholder comments had not passed at the time of writing (April 2020).

$\star \star \star *$ ) As the certificate for the Iceland lumpfish fishery was withdrawn 18 April 2019 (after having been suspended 4 January 2018), this is not a reassessment, but a new attempt at initial assessment. As the new assessment has just been announced at the time of writing (April 2020), scores and indication of conditions are based on the ACDR, hence only provisional. 


\section{Geir Hønneland}

team. This was partly the result of data collection initiated by the fishery client (by engaging scientists and independent observers in the fishery) to meet the conditions attached to its MSC certificate. This new information provided evidence to the effect that the 60 score threshold for PIs 2.2.1 and 2.2.2 was no longer met, which implied that the fishery now failed. The certificate was suspended in January 2018 and withdrawn in April 2019. In March 2020, a new attempt at initial certification was made. ${ }^{31}$ The ACDR, the first draft version of the assessment report published at the time of the fishery's announcement, only gives provisional scores, but at that stage data supported the assumption that all PIs will achieve a minimum of a 60 score, and the fishery will pass, albeit with new conditions related to the fishery's effects on the harbour seal stock. ${ }^{32}$

In summary, the Arctic inshore lumpfish fisheries, just like the Barents Sea fisheries, had a considerable number of conditions attached to their first (and some to their second) MSC certificate, some brought on by successful objections. This section has demonstrated how stakeholders such as NGOs and scientists have challenged assessment teams and provided new perspectives on the fisheries under assessment. But it has shown that 'complaints', whether in the form of stakeholder submissions or objections, do not automatically impact the outcome of assessments. The process is evidence based and the assessments carried out by assessors with relevant scientific background, most of them at $\mathrm{PhD}$ level. While their scoring of a fishery is not above criticism, it is seldom unfounded. There are also a number of procedural checks and balances in the CPR, including the authoritative decision making of the Independent Adjudicator. In brief, stakeholder submissions and objections provide an extra layer of quality check of assessment reports, beyond that of thorough external peer review and technical oversight by the MSC itself, and help sharpen the attention of the CABs and their assessment teams. But as a result of the thoroughness of the assessment work and comprehensiveness of MSC's procedural requirements, the bar is high for stakeholders to change the conclusions of the CABs. Of the five objections lodged against the assessments above, one was dismissed on procedural grounds. In the remaining four, some sort of compromise was found, although formally they were either partly dismissed, partly accepted or withdrawn.

\section{MSC certification of Arctic fisheries: outcomes}

"A completed condition means a fishery's score meets best practice," reads the MSC website, ${ }^{33}$ accompanied by the information that $92 \%$ of certified fisheries have had at least one condition attached to them, which must be met during the five-year validity of the certificate. From 2016 to 2018, 288 conditions were invoked, half of them on P2, the rest evenly distributed between P1 and P3. The most common type of action required was research, followed by assessment of the fishery's impact and "technical action" (such as gear modifications). ${ }^{34}$ While the previous section outlined how external actors have sought to affect the outcome 
of assessments, we now turn to the conditions set by the assessment teams and how fishery clients have gone about meeting the requirements of the conditions. How have they adapted their own behaviour, and to what extent have they succeeded in influencing management practice, including legislation, at the national and international levels? What has been achieved in terms of more sustainable fisheries management and fishing practices? ${ }^{35}$

In the Barents Sea fisheries, there were a few P1 and P3 conditions in the early assessments (see Table 1), but most conditions (and all conditions since 2013) have been on P2, in particular related to ETP species and habitats. All stakeholder submissions since 2013, and all three objections, have addressed the impact of bottom trawling on habitats. As we have seen, half of the clients in the Barents Sea are Russian fishing companies. Remarkably, given their unwillingness to share certificates, all the Russian clients have addressed their habitat-related conditions jointly; the scientific research institute PINRO and WWF-Murmansk (the local branch of WWF-Russia) are also on board. ${ }^{36}$ The cooperation between the companies involves four elements: first, a new semi-pelagic, 'near-bottom' trawl has been designed and tested, which, if put to use in the commercial fisheries, will reduce the impact on bottom habitats considerably. The project is financed by the clients jointly, according to an agreed cost distribution key. Second, a programme for registration of benthic encounters has been designed by WWF and put to use on client vessels. ${ }^{37}$ Third, the Russian clients have jointly created the Coordination Council for the Development of Sustainable Fisheries in the North and signed the Agreement on the Coordination of Actions of Fishing Companies to Minimize the Impact of Bottom Trawl Fishery on the Benthic Ecosystems in the Barents Sea and Norwegian Sea, both in $2016 .^{38}$ Fourth, under the Coordination Council agreement, the client companies have committed to not entering new fishing grounds in the Barents Sea (e.g. areas in the northern parts of the Barents Sea which are becoming more accessible due to changes in ice coverage) until these areas have been appropriately researched. ${ }^{39}$ Based on information in the annual surveillance audit reports, there is little doubt that these developments follow directly from the clients' endeavours to meet their MSC conditions. However, there is no evidence that management practice, national legislation or international agreement between Norway and Russia in their Joint Commission, have been affected by the MSC assessments. $100 \%$ of the Norwegian fleet and more than $85 \%$ of the Russian fleet are MSC certified, ${ }^{40}$ and the relevant authorities on both sides are consulted at each annual surveillance audit, so they are well aware of their national fleets being in the MSC programme. But there is complete silence about the private certification schemes from the responsible authorities. If you search for "MSC" or "Marine Stewardship Council" on the websites of Norwegian and Russian fisheries management bodies, ${ }^{41}$ or in the protocols of the Joint Norwegian-Russian Fisheries Commission, ${ }^{42}$ not a single hit comes up. Private certification is apparently not something they want to flag as part of the overarching management of the fisheries. ${ }^{43}$ 


\section{Geir Hønneland}

The conditions for third-country fisheries also relate in the main to P2, in particular to the protection of ETP species and habitat structures. The requirements to the fishery clients, which were all met during the five-year certification period, included recording of by-catch beyond what is required by Norwegian and Russian regulations; voluntary restraint to fishing grounds with historic footprint (documented to the assessment team at annual surveillance audits by vessel monitoring system (VMS) logs); production of company-level strategies, codes of conduct and action plans to avoid encounters with sponges and coral gardens; and obligatory training of crews on identification of ETP species and habitat structures. ${ }^{44}$

In the small-scale lumpfish fisheries, the direct effects of MSC certification are more immediately apparent. Problems identified at initial certification were lack of appropriate reference points, harvest control rules and management plans, as well as strategies to mitigate bycatch of seabirds and marine mammals. New reference points and harvest control rules have been produced in Greenland and are underway in Norway. ${ }^{45}$ Monitoring of the bycatch of seabirds (and in Iceland marine mammals) has increased in all three countries, and new mitigation strategies produced. ${ }^{46}$ Anecdotal evidence suggests that MSC certification is a "to be or not to be" requirement to get lumpfish roe sold on the global market, so fishing companies are prepared to go to great lengths to get the authorities to adopt the precautionary measures necessary for them to achieve and retain MSC certification..$^{47}$ In April 2020, the Icelandic Ministry of Fisheries and Agriculture was explicit about the role of certification in its press release about a precautionary seasonal halt of the lumpfish fishery, which was due to the need to keep fishing "in accordance with scientific advice" and "to ensure that the existing certifications are not lost." ${ }^{48}$ Hence, there is a direct link between MSC requirements and national regulations, as explicitly stated by the relevant authorities themselves.

\section{Conclusions}

All the major Barents Sea cod and haddock fisheries have been MSC certified since 2010 and the small-scale lumpfish fisheries since 2014. The incidence of conditions, stakeholder submissions and objections provides an indication of the state of the fisheries in question - the more of these, the more controversial the fishery. The most conspicuous trait in the Barents Sea fisheries is that all stakeholder submissions and objections (and practically all conditions) relate to P2, in particular to components 2.3 and 2.4 of the Assessment Tree, i.e. the protection of ETP species and habitats. First of all, this tells us that the status and management of the target stocks (P1), as well as the general functioning of the management regime (P3), are considered unproblematic and not in need of any additional action for 
the fishery clients in order to achieve and retain certification. This reflects the general view of the Barents Sea fisheries as well regulated within the established management structure at the national and international levels. The MSC programme is there to document that, but it does not add anything itself in terms of improved management.

Second, all but two fisheries had conditions related to ETP species or habitats in their initial assessment; half of them had stakeholder submissions on these issues, and two objections were lodged. At recertification, nearly half the fisheries still had conditions; nearly half received stakeholder submissions, and one certification was objected to. As a result of the three objections, additional conditions were introduced in two of the fisheries. This implies that nearly all fishery clients have been required to improve their efforts to avoid damage to ETP species and bottom habitats, e.g. through additional recording of catches, voluntary adherence to fishing grounds with historic footprints, production of company-level strategies to avoid encounters with sponges and corals; and obligatory training of crews on species identification. Most conspicuous are the joint efforts of the Russian fishery clients in this regard, not least the development of new fishing gear in cooperation with science and WWF. Equally notable is the absence of new regulations as a result of the MSC conditions. The effect of MSC certification in the Barents Sea is changed fishing practice, not changed management.

All the lumpfish fisheries received conditions at both initial assessment and reassessment; all received several stakeholder submissions; and two of three fisheries received an objection. One of the certificates was also withdrawn midway in the certification period. In other words, these are controversial fisheries which are balancing on the edge as far as MSC certification is concerned. On the other side of the coin, this provides an opportunity for the MSC to play a role. Essential parts of a management regime, such as biological reference points and harvest control rules, have in the Arctic lumpfish fisheries come about as a direct result of MSC certification. There is also evidence that authorities have justified practical management decisions with the need to keep the national fleet MSC certified.

MSC certification is no panacea, but it seems to have found a niche as a supplement to national legislation and international agreements. In the lumpfish fisheries, it became a catalyst for the speedy production of reference points and harvest control rules. In the Barents Sea, MSC served to fill an important gap in an otherwise well-developed management regime: the protection of bottom habitats. The MSC fishery clients (like the fisheries associations in Iceland and Norway and the individual fishing companies in Russia) are becoming important communication hubs, working with the authorities and science to meet the conditions imposed on them by the CABs in order to remain MSC certified. 


\section{Geir Hønneland}

\section{Appendix 1}

MSC assessment reports ${ }^{49}$

AGARBA (Spain) [AGARBA Spain Barents Sea cod] (1-FA 2013, Food Certification International; 1-SA 2015, 2-SA 2016, 3-SA 2017, 4-SA 2018, 1-RA 2019, Bureau Veritas (https://fisheries.msc.org/en/ fisheries/agarba-spain-barents-sea-cod/@@view)

Arkhangelsk Trawl Fleet (Russia) [Arkhangelsk Trawl Fleet Barents and Norwegian Seas cod, haddock, saithe and Greenland halibut] (1-FA 2016, 1-SA 2017, 2-SA 2018, Acoura Marine; 3-SA 2019, Lloyd's Register) (https://fisheries.msc.org/en/fisheries/arkhangelsk-trawl-fleet-norwegian-barents-seas-codhaddock-saithe-greenland-halibut/@@view)

Faroe Islands/Iceland [Faroe Islands and Iceland North East Arctic cod and haddock] (1-FA 2012, 1-SA 2013, 2-SA 2014, 3-SA 2015, 4-SA 2016, 1-RA 2017, DNV GL) (https://fisheries.msc.org/en/fisheries/faroeislands-and-iceland-north-east-arctic-cod-haddock-and-saithe/@@view)

FIUN (Russia) [FIUN Barents \& Norwegian Seas cod and haddock] (1-FA 2013, 1-SA 2014, 2-SA 2015, Food Certification International; 3-SA 2016, 4-SA 2017, 1-RA 2018, Acoura Marine) (https://fisheries. msc.org/en/fisheries/fiun-barents-norwegian-seas-cod-and-haddock/@@view)

Greenland [Greenland cod, haddock and saithe] (1-FA 2015, Intertek Fisheries Certification, 1-SA 2016, 2-SA 2017, 1-RA 2019, Acoura Marine) (https://fisheries.msc.org/en/fisheries/greenland-cod-haddockand-saithe-trawl-fishery/@@view)

Greenland lumpfish [Greenland lumpfish] (1-FA 2015, 1-SA 2016, 2-SA 2017, 3-SA 2018, 4-SA 2019, 1-RA 2020, DNV GL) (https://fisheries.msc.org/en/fisheries/greenland-lumpfish/@@assessments)

Iceland lumpfish [Iceland Gillnet lumpfish] (1-FA 2014, 1-SA 2015, 2-SA 2016, 3-SA 2017, Vottunarstofan Tún) (https://fisheries.msc.org/en/fisheries/icelandic-gillnet-lumpfish/@@assessments) Fishery withdrawn in 2017; entered new assessment in 2020 under the name "ISF Iceland lumpfish" (2-FA 2020, SAI Global) (https://fisheries.msc.org/en/fisheries/isf-iceland-lumpfish/@@assessments)

Murmanseld 2 (Russia) [Murmanseld 2 Barents Sea cod and haddock] (1-FA 2020, DNV GL) (https:// fisheries.msc.org/en/fisheries/murmanseld-2-barents-sea-cod-and-haddock/@@view)

Norway lumpfish [NFA Norway ling \& tusk and NFA Norway lumpfish] (1-FA 2017, Acoura Marine; 1-SA 2019，2-SA 2020, DNV GL) (https://fisheries.msc.org/en/fisheries/nfa-norway-ling-tusk-and-nfanorway-lumpfish/@@assessments)

Norway (Norw. Seafood Council) [Norway North East Arctic cod] (1-FA 2010, 1-SA 2011, 2-SA 2012, 3-SA 2013, 4-SA 2014, 1-RA 2015, DNV GL) (https://fisheries.msc.org/en/fisheries/norway-north-eastarctic-cod/@@assessments)

Ocean Trawlers (Russia) [Barents Sea cod, haddock and saithe] (1-FA 2010, 1-SA 2011, 2-SA 2012, 3-SA 2013, 4-SA 2015, Food Certification International; 1-RA 2016, Acoura Marine) (https://fisheries.msc. org/en/fisheries/barents-sea-cod-haddock-and-saithe/@@view)

Oceanprom (Russia) [Oceanprom Barents Sea cod and haddock] (1-FA 2019, DNV GL) (https://fisheries. msc.org/en/fisheries/oceanprom-barents-sea-cod-and-haddock/@@assessments)

Saint Malo/Euronor (France) [Compagnie des Pêches Saint Malo and Euronor cod and haddock] (1-FA 2012, 1-SA 2013, 2-SA 2014, MacAlister Elliott and Partners Ltd.; 3-SA 2015, 4-SA 2016, 1-RA 2017, ME Certification Ltd.) (https://fisheries.msc.org/en/fisheries/compagnie-des-peches-saint-malo-andeuronor-cod-and-haddock/@@view)

Strelets/Eridan (Russia) [Russian Federation Barents Sea cod, haddock and saithe] (1-FA 2014, 1-SA 2015, 2-SA 2016, 3-SA 2017, 4-SA 2018, 1-RA 2019, DNV GL) (https://fisheries.msc.org/en/fisheries/ russian-federation-barents-sea-cod-haddock-and-saithe/@@view)

UK Fisheries/DFFU/Doggerbank [UK Fisheries Ltd./DFFU/Doggerbank Northeast Arctic cod, haddock and saithe] (1-FA 2012, 1-SA 2013, 2-SA 2014, MacAlister Elliott and Partners Ltd., 3-SA 2015, 4-SA 2016, 1-RA 2017, ME Certification Ltd.) (https://fisheries.msc.org/en/fisheries/uk-fisheries-ltd-dffudoggerbank-northeast-arctic-cod-haddock-and-saithe/@@view) 


\section{NOTES}

1. See https://www.ourgssi.org/. Local standards Responsible Fisheries Management (RFM) standards for Alaska and Iceland achieved accreditation before the MSC.

2. See https://www.msc.org/.

3. See, e.g., Kar H. Lim, Wuyang Hu, Rodolfo M. Nayga Jr., "Is Marine Stewardship Council's Ecolabel a Rising Tide for All? Consumers'Willingness to Pay for Origin-Differentiated Ecolabel Canned Tuna," Marine Policy 96 (2018): 18-26.

4. See, e.g., Lars H. Gulbrandsen and Graeme Auld, "Contested Accountability Logics in Evolving Nonstate Certification for Fisheries Sustainability," Global Environmental Politics 16 (2016): 42-60.

5. See, e.g., Ashleigh Arton, Anthony Leiman, Gillian Petrokofsky, Hilde Toonen and Catherine S. Longo, "What do We Know about the Impacts of the Marine Stewardship Council Seafood Ecolabelling Program? A Systematic Map," Environmental Evidence 9 (2020): 1-20. This is just a small selection of topics covered in the literature about MSC. A search in the Web of Science database for academic journals (www.webofknowledge.com) (accessed 21 April 2020). generates 161 articles, of which 131 have been published since 2012. The largest disciplinary categories are Environmental Studies (53), Fisheries (41) and International Relations (39). A large number of the articles are empirical studies of MSC assessments in specific geographic regions. I have not come across other studies of MSC assessments in the Arctic, but some of the Russian Barents Sea fisheries are analysed in articles about MSC assessments in Russia (Lars H. Gulbrandsen and Geir Hønneland, "Fisheries Certification in Russia: The Emergence of Non-State Authority in a Postcommunist Economy," Ocean Development and International Law 45 (2014): 341-359; Dmitry Lajus, Daria Stogova and E. Carina H. Keskitalo, "The Implementation of Marine Stewardship Council (MSC) Certification in Russia: Achievements and Considerations," Marine Policy 90 (2018): 105-114; Alexey O. Pristupa, Machiel Lamers and Bas Amelung, "Private Informational Governance in Post-Soviet Waters: Implications of the Marine Stewardship Council Certification in the Russian Barents Sea Region,” Fisheries Research 182 (2016): 128-135).

6. I have to make a certain analytical reservation with regard to causation. It may be possible to point empirically to a chronological link between MSC certification, revised regulations and fisher behaviour, and sometimes the sources (i.e. MSC assessment reports) claim that there is also a causal link. However, it goes beyond the ambition of this article to test alternative explanations to the observed behaviour.

7. In the Barents Sea, MSC coverage is close to 100 per cent for the commercial demersal species taken by Norway, Russia and third states. All three commercial lumpfish fisheries in the Arctic (the Greenlandic, Icelandic and Norwegian) are MSC certified (the Icelandic fishery admittedly withdrew in 2019 , but is applying for a new certificate in 2020). The three countries have a high coverage of MSC certification in general. In both Iceland and Norway, certification is taken care of by associations (Iceland Sustainable Fisheries and the Norwegian Fishermen's Association, respectively) and the certificates made available to the entire national fleets.

8. "Avtale mellom Regjeringen i Unionen av Sovjetiske Sosialistiske Republikker og Regjeringen i Kongeriket Norge om samarbeid innen fiskerinæringen," ("Agreement between the Government of the Union of the the Soviet Socialist Republics and the Kingdom of Norway on Cooperation in the Fishing Industry"), in Overenskomster med fremmede stater ("Agreements with Foreign States”), Oslo: Ministry of Foreign Affairs, 1975, pp. 546-549.

9. Three additional stocks have later been added to the list of joint stocks: capelin $(60 \%$ to Norway, $40 \%$ to Russia), Greenland halibut (51\% to Norway, $45 \%$ to Russia and $4 \%$ to 


\section{Geir Hønneland}

third countries) and beaked redfish (72\% to Norway, $18 \%$ to Russia and $10 \%$ to third countries).

10. See, e.g., Protokoll for den 49. sesjon i Den blandede norsk-russiske fiskerikommisjon ("Protocol from the 49th Session of the Joint Norwegian-Russian Fisheries Commission"), Appendix 3, Petrozavodsk, 17 October 2019; available at https://www.jointfish.com/ OM-FISKERIKOMMISJONEN/PROTOKOLLER.html (accessed 29 June 2020).

11. For an overview, see Geir Hønneland, Making Fishery Agreements Work: Post-Agreement Bargaining in the Barents Sea (Cheltenham: Edward Elgar Publishing, 2013).

12. I am myself a certified MSC auditor and have been involved in fishery assessments as an expert on MSC Principle 3 (the management system). This includes the Russian Barents Sea fisheries and the Norwegian and Icelandic (second attempt) Arctic lumpfish fisheries discussed in this article. My practical experience and training in applying the MSC Standard have helped me navigate the voluminous body of documentation available on MSC assessments. The empirical investigation is based solely on publicly available documents - hence, I see no conflict of interest or other ethical problems.

13. MSC Fisheries Standard Version 2.01, 31 August 2018 (effective 28 February 2019), London: Marine Stewardship Council; available at https:/www.msc.org/docs/default-source/ default-document-library/for-business/program-documents/fisheries-program-documents/ msc-fisheries-standard-v2-01.pdf?sfvrsn=8ecb3272_13 (accessed 29 June 2020).

14. MSC Fisheries Certification Process Version 2.1, 31 August 2018 (effective 28 February 2019), London: Marine Stewardship Council; available at https://www.msc.org/docs/defaultsource/default-document-library/for-business/program-documents/fisheries-programdocuments/msc-fisheries-certification-process-v2.1.pdf?sfvrsn=5c8c80bc_24 (accessed 29 June 2020).

15. The Guidance states that "outstanding disputes of substantial magnitude involving a significant number of interests will normally disqualify a fishery from certification. However, the existence of controversies or disputes are of themselves not enough to stop a fishery from being eligible for certification. [...] The judgement should be whether a dispute compromises the ability of the management system to provide sustainable management." (G7.4.5)

16. MSC Fisheries Standard, p. 11.

17. A harvest control rule is defined as "a set of well-defined pre-agreed rules or actions used for determining a management action in response to changes in indicators of stock status with respect to reference points" (MSC-MSCI vocabulary, available at https://www.msc.org/docs/ default-source/default-document-library/for-business/program-documents/chain-of-custody-supporting-documents/msc-msci_vocabulary_v1-2.pdf?sfvrsn=cef284dd_14) (accessed 22 August 2020).

18. MSC Fisheries Standard, p. 5.

19. MSC Fisheries Standard, p. 27

20. MSC Fisheries Standard, p. 5.

21. MSC Fisheries Standard, p. 62.

22. All information in the text below refers to the two tables in this section, one for each cluster of fisheries. That information, in turn, is taken from the assessment reports for each fishery listed in Appendix 1. It follows from the context which report each piece of information is taken from; for example, all information about the Ocean Trawlers assessment is taken from the assessment report for that fishery listed in Appendix 1. All information on fulfilment of previous conditions is taken from the $4^{\text {th }}$ surveillance audit report in the preceding certification cycle. Page reference is only provided for direct citations, using the coding provided for in the footnote of the Appendix (e.g., 1-FA $=1^{\text {st }}$ full assessment report; 4-SA $=4^{\text {th }}$ surveillance audit report). 
23. The P1 conditions had to do with the Joint Norwegian-Russian Fisheries Commission departing from the restraint in the harvest control rule not to raise the cod TAC by more than $15 \%$ from one year to another, which it had done in a year with exceptionally high stock biomass. The P3 conditions required lobbying from the client in order to propagate precaution in Russian fisheries legislation and the inclusion of NGOs in consultation mechanisms.

24. International disagreement on the status of the Fishery Protection Zone around Svalbard has not been an issue in any of the other Barents Sea assessments as the assessment teams have observed that the legal disagreement among states has not had adverse impacts on the effectiveness of the management of the Barents Sea fisheries. In the UK/DFFU/Doggerbank fishery, the assessment team, noting that it was not competent to make any legal judgement of the issue, leaned on the fishery client's opinion and concluded that the quota distribution in the Svalbard zone was "unfair" (1-FA, p. 48). The condition required the client to engage with EU bodies of governance and urge them to bring "the Svalbard dispute" up with Norwegian authorities. According to the ensuring annual surveillance reports, the client did that, without the "dispute" being solved or EU authorities even making an effort to bring this up with Norway. The condition was not repeated when the fishery was recertified five years later. In later versions of the MSC Standard, the requirements for harmonization among fisheries have become much stricter and it would no longer be possible for only one fishery to have a condition for an alleged shortcoming that is common to all fisheries in the area.

25. The MSC Interpretations Log (https://mscportal.force.com/interpret/s/) is a tool for CABs, assessment teams and the ASI to ensure consistent interpretation of the Standard and its Guidance. It contains authoritative interpretations of specific requirements based on dilemmas that have emerged in the practical application of the Standard. Interpretations are sometimes included in the Guidance in its subsequent five-year revision.

26. Murmanseld 2 assessment, 1-FA, p. 289.

27. Individual fishing companies were the clients for the Icelandic and Greenlandic fisheries, whereas the Norwegian Fishermen's Association was the client for the Norwegian fishery.

28. Iceland lumpfish assessment, 1-FA, p. 259.

29. Greenland lumpfish assessment, 1-FA, p. 261.

30. One might wonder how new conditions can be introduced at reassessment as one might expect any problems in the fishery to be detected at initial assessment and mitigated by the work to close conditions. While the situation in the fishery might have changed, new conditions are most often the result of revisions of the MSC Standards. With every five-year revision, the requirements of the Standard get stricter. This has in particular been the case for P2 as ecosystem considerations have been given ever more attention.

31. This time the client was Iceland Sustainable Fisheries (ISF), an industry alliance set up to facilitate MSC certification of all Icelandic fisheries.

32. Iceland lumpfish 2-FA

33. https://www.msc.org/what-we-are-doing/our-collective-impact/fisheries-improving (accessed 29 June 2020).

34. Ibid.

35. Just like in the last section, all information is taken from the MSC assessment reports for the respective fisheries; see Appendix 1 for list of reports and their coding for reference.

36. See, e.g., the FIUN assessment, 1-RA, p. 179.

37. Ibid., p. 189.

38. See, e.g., the FIUN assessment, 1-SA (under first reassessment), p. 16.

39. By contrast, the achievements of the Norwegian client are less clear - as opaquely described in the $4^{\text {th }}$ surveillance audit report to sum up activities over the last five-year period: "The client engaged with IMR and DoF from the time of the original certification to formalise earlier voluntary arrangements for minimising adverse interactions between fishing and 


\section{Geir Hønneland}

sensitive marine habitats. Vessels continue to contribute data to the MAREANO programme on an opportunistic basis." (Norway (Norw. Seafood Council) assessment, 4-SA, p. 27).

40. All Norwegian vessels are covered by the Norway North East Arctic cod certificate. The number of Russian vessels certified is approximate, based on the numbers of vessels indicated in the various assessment reports.

41. https://www.regjeringen.no/no/dep/nfd/id709/ (Ministry of Industry and Fisheries, Norway), https://www.fiskeridir.no/ (Directorate of Fisheries, Norway), http://www.fish.gov.ru/ (Federal Fisheries Agency, Russian Federation) (accessed 20 May 2020).

42. https://www.jointfish.com/ (website of the Joint Norwegian-Russian Fisheries Commission) (accessed 20 May 2020).

43. A reason for this might be that authorities view the MSC as a "competitor" and/or inappropriate "intruder" in national fisheries management. Admittedly, Norwegian authorities have contributed to MSC certification of Norwegian fisheries through the Norwegian Fishermen's Association and Seafood Council, but that does not mean that they have done so with enthusiasm. More importantly, civil servants set to manage Norwegian fisheries might not embrace requirements from MSC assessment teams (through the MSC clients) to adjust Norwegian regulations in accordance with the MSC Standard, which is generally perceived as a straightjacket designed to fit all types of fisheries, small- or large-scale, around the world. It should be noted that this is based on the author's personal observation and has not been part of the investigation on which this article is built.

44. See, e.g., Greenland cod and haddock assessment, 3-SA, pp. 18-19.

45. Greenland lumpfish assessment, 4-SA, pp. 26-27; Norway lumpfish assessment, 2-SA, pp. 37-43.

46. Greenland lumpfish assessment, 4-SA, pp. 28-30; Iceland lumpfish assessment, 3-SA, pp. 17-20; Norway lumpfish assessment, 2-SA, pp. $39-43$, p. 51.

47. Anecdotal evidence, based on the author's own experience.

48. https://www.stjornarradid.is/efst-a-baugi/frettir/stok-frett/2020/04/30/Breyting-a-reglugerdum-veidar-a-grasleppu-2020/, accessed 30 April 2020. The English formulation follows from Google translate. The statement was imprecise in that the certificate was already lost, but assessment was underway to get it reinstated.

49. In this list of MSC assessment reports, the short name given in Tables 1 and 2 are provided first. The official MSC names follow in square brackets, for reference in the MSC website's "Track a Fishery" function (https://fisheries.msc.org/en/fisheries/). FA = full assessment; $\mathrm{SA}=$ surveillance audit; RA = reassessment. Hence, 2 -SA means the second annual surveillance audit in the five-year certification cycle. The names of the certification bodies, as formal publishers of the reports, are also given. "1-FA 2010, 1-SA 2011, 2-SA 2012, 3-SA 2013, 4 -SA 2014, Moody Marine; 1-RA 2015, Food Certification International” means that all reports up until 2014 were published by Moody Marine, while the 2015 report was published by Food Certification International. 